\title{
THE VALUE SYSTEM AND LOCUS OF CONTROL IN STUDENTS
}

\begin{abstract}
Dealing with the analysis of the values and locus of control, the questionnaire for measuring internal locus of control and the scale for measuring preferences of lifestyles was applied on the sample of 1,146 students. The results confirmed the relation of the value orientations and locus of control in students and pointed out statistically significant differences in students from different faculties regarding lifestyle and internal locus of control. It was confirmed that, according to the lifestyle variable, students of theology show statistically different results from other students. Domination and religiousness bring about this difference to the highest level. The results of analyses in the area of internal locus of control suggest that students from the Faculty of Theology are significantly different from the others in relation to the passive strategy of facing problems.
\end{abstract}

Keywords: individual characteristics, lifestyle, locus of control, youth.

\section{Introduction}

The value system presents an essential component of an individual's personality. $\mathrm{Hu}-$ man values are defined as cognitive constructs that explain individual differences in lifetime goals and behaviour and the principle of priority (Renner, 2003). Ten basic values include all of the key values that are recognized in different cultures in the world (Shwartz, 2006). Each of the basic values is characterized by the description of the main motivational goal: self-direction (independence in action, choice, design, research); stimulation (excitement, novelty, challenges); hedonism (pleasure and enjoyment); achievement (personal success shown as a demonstration of competence in relation to people and resources); power (social status, prestige, control of dominance over people and resources); security (security, compliance and stability of the society, in relationships and in personality); adaptation (abstinence of action, intention and impulses that can disturb and undermine social expectations or norms); tradition (respect, commitment and acceptance of customs and ideas of traditional culture or religion); charity (care for the welfare of those to whom we are related); universality (understanding, tolerance, protection of people and goods). Therefore, it can be concluded that the values affect most, if not even all types of motivational behaviour (Babić, Irović, \& Krstović, 1997; Dragun, 2012; Havelka, 1995; Sekulić, 
2011). At the same time, the external values are focused on honours and awards, while the inner values are more related to the things that we have achieved and perceived as successful (Kuburić, 2002; Maslow, 2001; Roccass, Sagiv, Schwartz, \& Knafo, 2002).

The concept of values, with regard to its essential content and meaning, is related to the concept of lifestyle. Every choice is an expression of the design of a person's own life, and some of them, according to Popadić (1995), have been selected automatically, while the others are outcomes of the thought process. The author also points out that the fundamental question that arises from the analysis of particular lifestyles is not whether someone likes or wants something, but whether the person is ready to arrange his or her lifestyle structures so that other activities become subordinated to the achievement of the priority goals (Adler, 1989; Popadić, 1995). In their life orientation and their lifestyles some individuals are more focused on religion, others on a sport or a technique, while the value system of humanistic oriented persons is directed towards the man, his existence and his psychosocial development.

The locus of control is a basic dimension of personality that in short can be defined as the level to which people believe they have control over events. In other words, in determining locus of control, the key concept is the perception of a place or localization of lower or greater control over the outcomes of an individual's behaviour. The locus of control first appears as a central construct of Rotter's Social learning theory (1954). It also takes a significant place in Seligman's probability analysis (1975), and in Weiner's attributional analysis of motivation and emotion (Weiner, 1986).

In terms of Rotter's theory, the locus of control represents a relatively stable predisposition of personality to an internal or to an external locus of control. Self-efficacy, as an essential component of an individual's locus of control, is a significant determinant in setting and implementing goals. Authors point out that the belief of individuals in their effectiveness depends on their attempts to establish control over events and thus expectations of positive outcomes (Taylor \& McDonald, 1999).

In his approach to the locus of control, depending on goals, Popadić (1986) distinguishes three forms: locus of causality, observed control and assuming responsibility. If the locus of control is interpreted as one dimension, it will represent belief to what extent an outcome of an event depends on external or internal factors. The locus of control, seen as an observed control of internal orientation, can be represented as the possibility of achieving established goals. However, individuals with the internal locus of control may fall into the trap of helplessness, when the success-defining factors are external and unfavourable for them. In contrast, externally oriented individuals may feel power in the situation when they resort to rituals in an attempt to propitiate, for example, the powerful people. IT confirms that success factors can also be external and internal. Assuming responsibility as the third form of the locus of control represents the willingness to accept responsibility, having in mind that the same situation of succss or failure can be interpreted difrerently (Popadić, 1986).

Considering the characteristics and the individual perception of events, two main forms of locus of control can be described more precisely. The internal locus of control is the characteristic of those individuals who believe that their own experiences are determined by their own skills and effort. High probability of events among internally oriented individuals is under their control. Characteristics of internalists are reflected in their ten- 
dency to anticipate the possibility of control, so they choose the situations that allow them to verify this control.

On the other hand, people who mostly have an external locus of control, or persons of external orientation, place individual expectations under the control of external factors (luck, authority, accidents, difficulty of the task, etc.), and this is the reason for their tendency to lack resistance and have low expectations. Externalists elect those situations that release themselves of responsibility. However, the strict division between externalists and internalists is not valid, considering the existence of a large number of individuals belonging to the mixed type. Also, there is an interesting statement by Neill (2005) about the importance of warning people that they should not naively accept the idea that the internal locus of control is good, and that the outside one is bad.

The locus of control can be associated with a number of processes and functions of individuals. This personality variable is significantly involved in defining academic success, and this is confirmed by the analysis of internal/external orientation. Understanding the effects of control and taking some steps towards the adequate orientation can lead to more efficient education. Strickland (1988, according to Hewes \& Hillman, 2001) points out to children with greater internal score, who show better adaptive behaviour and better academic performance. In the same manner, Bender (1995) believes that continued failure, despite continuous attempts of solving school tasks, leads to the adoption of the external locus of control, which, in turn, leads to the lack of motivation for learning.

The study conducted using the data from the study Value system of the young and social changes in Croatia, of the Institute for Social Research in Zagreb, on a representative sample of 1, 700 young people of both sexes, aged 15-29 years (Ilišin \& Radin, 2002), was aimed at analyzing the effect of socio-demographic variables - gender, age, education, place of residence and marital status on the understanding of values in respondents (Bouillet, 2004). The results showed that all the five tested socio-demographic characteristics among the young influenced their family values. The place of residence and the level of education of the respondents proved to be the factors that were most related to values of young people, followed by gender and marital status, while the least associated with values was the age of the respondents.

The study of the phenomenon of values and value orientations of young people that has been conducted on the sample of 252 students, future teachers and educators, by applying Rokeach lists of values, showed that there was a high degree of uniformity of results among students, in case of terminal values representing desirable situations and goals, while there were some differences in terms of instrumental values, regarding idealized behaviours with the aim of achieving terminal values. It was also found that the students at teacher education faculties were oriented toward family safety, happiness, true friendship, inner harmony, which all represent their dominant terminal values, while honesty, responsibility and capability were distinguished among instrumental values (Bojović, Vasiljević, \& Sudzilovski, 2015).

The study conducted in 2009 on a sample of 254 higher grades of secondary schools in Zadar showed the results similar to those acquired in other regions of Croatia. The results showed that among the tested values the young appreciated most the aspects of values referring to good relations with other people, so the outstanding values were friendship, good family relations, honesty and love, apart from health, which also proved to be 
a dominant value among the young. The results indicate that the values of conventional moral orientation constitute the main connecting factor with striving for self-accomplishment (Dragun, 2012).

The study conducted by Popadić (1995) determined the following dominant lifestyles on a sample of adolescents: family-sentimental, altruistic, cognitive and utilitarian, while religious-traditional orientation and the orientation to power showed as the least popular lifestyles. Exploring the lifestyles of young people, Mladenović and Knebl (2000) came to three major factors. In the first set of lifestyles, the factor that represents the lifestyle was centred on the individual. Orientation to the primary group and to the wider community defines the other identification factor, but in the third set of lifestyles, which is focused on general human values, dominates the cognitive, promethean and altruistic lifestyle. The research on lifestyles, interests and values within Shell's study in Germany (Shell, 2002, as cited in Becker, 2004) was conducted on a sample of 2,500 respondents aged 12-25 years, and it showed that family and school were important lifestyle factors and values for young people.

A study conducted on the student population, which was aimed at testing students' attitudes towards presence, characteristics and causes of the crisis in moral values within the society, with special reference to the perception of the relationship of moral values and the factors of family influence, schools and other social institutions, showed that in these terms they distinguished the role of family, school and the media, as well as their interactions affecting the formation of moral values of children and young people. However, the concerning fact was that fear, uncertainty, pessimism and distrust in their own personal abilities dominated among the students regarding the possibilities for reducing the crisis of moral values. In addition, there was a certain inconsistency among the students when it came to moral action (Budimir-Ninković \& Stevanović, 2013).

Findings of the research conducted by Sakač and Mladenović (2005) on a representative sample of students in grammar schools and high schools in Novi Sad about the internal locus of control, as an important determinant in the multivalued forms of achievement and competence, pointed to the various forms of the internal locus of control. One of them is related to the control of academic achievement, and individual competence in the area of decision-making and work, and the other to emotional competence (Sakač \& Mladenović, 2005). Mamlin, Harris, and Case (2001, as cited in Neill, 2005) found a regularity which showed that men were more prone to the internal locus of control when compared to women.

In the test conducted by Ule and Kuhar (2002) on a sample of Slovenian youth, health is at the top of the scale, followed by sincere friendship, family life and freedom of thought and action. The first three values reflect traditionalism and matters of a personal nature, while the fourth value is an example of an expressive value, which is associated with the idealistic conception of the world and life. Among the values that the respondents evaluate as the lowest is the distinctive status group of materialistic and hedonistic values (good financial situation, exciting life, authority, leadership and power over others). By comparing the results of Youth 2010 tests with Youth 2000 tests, it can be concluded that the interests were rated lower, whereas there was an increasing interest in the enjoyment of food and drink (Naterer \& Quiet, 2011). 
Aluja and Garcia (2004) have identified three factors - social power, order and charity, in the set of 25 values. Most young people in Russia are characterized by the values related to financial status (Zorkaia \& Duik, 2005). On that occasion, only half of the respondents considered higher education as a precondition for success in life, while the youngest respondents (between 16 and 19 years old) valued higher education highly.

Based on the presented theoretical concepts (Roccas et al., 2002; Shwartz, 2006; Seligman, 1975; Taylor \& McDonald, 1999) and the results of the previous studies, which show the existence of differences in the values and the locus of control between young people of different educational and professional orientations and of different gender (Bojović et al., 2015; Bouillet, 2004; Ilišin and Radin, 2002; Marić \& Novović, 2010; Marin, Infante, \& Troyano, 2001; Mamlin et al., 2001, according to Neill, 2005; Popadić, 1995), the basic assumption of this study is that the relation between value orientations and locus of control exists, and that students of different faculties and different gender differ in the preferential living values and the degree of possession of the internal locus of control.

\section{Methods}

The problem of this research is the question whether there is relation between the value system and locus of control, and whether and to which level students' characteristics regarding their gender and professional orientation are related to their value system and their internal locus of control.

Accordingly, the aim of the research is to examine the relation between the value system and locus of control in students, and to determine the existence of differences in the value and control system of the students, considering their gender and type of study.

The survey was conducted during the academic 2014/15 year on the sample of 1,146 students of both sexes, 636 male (55.49\%) and 510 female (44.51\%), of the average age of 21.79 years, years of study: 1 to 4 (5). The structure of the sample is shown in Table 1 The sample is random. Four faculties were included and the tendency was to include faculties of different educational orientations. The total number of the participants was determined proportionally to the total number of the students of each faculty included in the sample.

When it comes to ethical principles, the research was anonymous. The respondents were told that the data would be used exclusively for research purposes. The consent was provided of the ethics committee of the institution in which the research was conducted.

Instruments used in this study were the following:

- Scale for measuring lifestyle preferences, V-PAL (Values - desirable attributes of personality, Havelka, 1998) - includes a series of twelve descriptions of evaluating lifestyle orientations. Each description is formulated in the form of the statement where the level of agreement is estimated by the five-level scale of rating, choosing one of the five offered answers (from "I do not agree" to "I completely agree"), so the higher level of agreement represents the more accepted given value. Six value orientations signify the focus on individual goals: security (existential security - example of items: have a stable and secure job, which ensures a decent and safe life, diligent work to ensure the satisfaction of individual needs), earnings (material benefit - have high profits, be rich), independence from others (decide independently, to be independent in work, independent from others), hedonism (deal with jobs in which there is not much effort, 
live happily and carelessly, with benefits and pleasures), refinement (self-actualization - constantly develop abilities, self-reliance, talents and ambitions, and develop as a personality), religiousness (commitment to faith - respect the rules and requirements of faith, harmonize life and customs with religion). Six value orientations signify the focus on social goals: domination or influence (social power - manage, make important decisions, be an influential person), popularity (status in public life - be known and popular, appear in the media), learning (exploration - discovering new things, dealing with science and research), cooperation (cooperative spirit - respect others, build cooperation, tolerance and fellowship), help (altruism - helping people in trouble, doing good things even at the expense of great sacrifice and efforts), justice (Prometheus-like - creating a better and just society, eradication of poverty and evil, with great efforts). The total score is represented as a summative result of the values achieved on the items that indicate six factors of individual and social goals. The scale has satisfactory metric indicators Cronbach $\alpha$ is 0.78 , test - retest reliability is 0.72 , whereas Cronbach $\alpha$ was also high in this study and amounted to 0.75 .

- Scale for measuring the internal locus of control, LOK IM-2, which consists of 16 four-level Likert type items with the choice of alternative answers: completely true, partly true, partly untrue, completely untrue. The high score on the scale indicates internal orientation. On the contrary, low scores indicate that the respondent has no internal locus of control, but it does not necessarily mean that at the same time the respondent has an external locus of control, although such a possibility is not excluded. The scale LOK IM-2 is a shortened and revised form of the scale LOK IM-1 (Sakač, 2003). The examples of items are: My school achievement depends largely on my abilities and effort, I am trying to solve the difficulties because they will not simply disappear, I think my future depends mostly on me, My relationship with others mostly depends on me and my behaviour, How much I will succeed in my life depends most on me, etc. Metric characteristics of the scale are the following: Cronbach $\alpha=0.75$ and standardized coefficient $\alpha$ is 0.76 . Relatively good psychometric properties of this scale recommended its usage, as was shown in this study $(\alpha=0.71)$. The item-total correlations range from 0.64 to 0.85 , with an average inter-item correlation of 0.76 (in this study 0.73 , which indicates that the scale has a satisfactory internal coherence). The factor structure also shows that the scale has a unique object of measurement, with factor saturation ranging from 0.79 to 0.94 .

\section{Results}

Within the statistical data processing, the multiple regression analysis was used for the examination of the relation between the locus of control and value orientations of students. In the regression, the criteria variable was the locus of control while the predictors were six individual and social value orientations. Two-factor ANOVA was used for examining gender and faculty differences in the locus of control and value orientations among students. The factor analysis was previously conducted with the aim of determining the latent structure of variables.

Table 2 and Table 3 shows the results of the analysis of variance (ANOVA), which examined the differences among students in terms of preferences of the lifestyles. Since 
the sample size in the categories was different, Leven's test was applied in determining the assumption of homogeneity of the variance. The value of Leven test showed that the assumption was respected (Lev.stat. $=1.18 ; \mathrm{p}=0.734$ for influence; Lev.stat. $=1.12 ; \mathrm{p}$ $=0.693$ for religiousness), indicating that the test was applied under the assumption of homogeneous variance. These results confirm that there are statistically significant differences between respondents of different faculty affiliation in the components of lifestyles - influence and religiousness, while gender and interaction between faculty and gender did not prove to be significant. Scheffe's test has confirmed that students of the Faculty of Theology significantly differ from students of other faculties $(p<.000)$. The lowest level of the observed differences in the components of lifestyles has been observed between the students of the Faculty of Technical Sciences and the students of the Faculty of Sport and Physical Education.

Considering that the first principal component previously distinguished by factor analysis from the lifestyle domain is characterized by a high score on the dimensions of influence and religiosity (average correlation of items with a factor is 0.64 ), the research shows that the presence of this lifestyle is mostly preferred by the students of Faculty of Theology, less by the students of the Faculty of Sport and Physical Education and the Faculty of Technical Sciences, and least by the students of the Faculty of Philosophy.

The tests of the significance of differences in the domain of the internal locus of control Table 4 confirmed the presence of significant differences among students from different faculties, whereas gender and the interaction of faculty and gender did not prove to be significant here either. Since the sample size in the categories was different, Leven's test was applied in determining the assumption of homogeneity of the variance. The value of Leven test showed that the assumption was respected (Lev.stat. $=1.26 ; \mathrm{p}=0.827$ ), indicating that the test was applied under the assumption of homogeneous variance. According to the results of Scheffe's test, the highest differences were found between the students of the Faculty of Theology, on the one hand, and the students of the other faculties, on the other hand. Moreover, this test allows the conclusion that there were no confirmed differences among students of other faculties (the Faculty of Technical Sciences, the Faculty of Philosophy and the Faculty of Sport and Physical Education). Since the first principal component was previously isolated in the domain of the internal locus of control, and named a passive strategy of dealing with the problem (average item-factor correlation is 0.68 ), which reflected the characteristics of low internal orientation, among the students of the other faculties this indicated their higher or lower internal orientation or the internal locus of control.

Tables 5 and 6 show the results of the multiple regression analysis testing the relation between the locus of control and value orientations of the students. The criteria variable was the internal locus of control, while the predictors were six value orientations - individual and social.

Based on these results, it can be concluded that there is a high level of correlation between the criteria and predictor variables.

The Table 6 shows that significant predictors of the internal locus of control in the students are values orientations - independence from others, refinement and learning. Values orientations - religiousness, cooperative spirit-respect for others and help are negatively correlated with the internal locus of control. 


\section{Discussion}

The main aim of the research was to examine the relation between the value system and the locus of control in students. Its results showed that different goals within groups of individual and social value orientations were significant predictors of the internal locus of control in students. Within individual value goals, independence from others, refinement and religiousness proved to be significant predictors of locus of control. Learning, cooperative spirit - respect for others and help are social value orientations which significantly predict the locus of control among students.

It can be concluded that young persons with a strong tendency of being independent from others and striving for self-actualization, constantly learning and developing their abilities, talents, ambitions and personality, have a predisposition for the internal locus of control. Also, those young people with a tendency towards religiousness, with a cooperative spirit and propensity for respecting and helping to others, are less likely to have the internal locus of control, but it still does not mean that they will certainly manifest characteristics of the external locus of control.

These results are expected regarding the dominant theories of the locus of control (Taylor \& McDonald, 1999; Weiner, 1986) and value goals (Havelka, 1995; Renner, 2003; Shwartz, 2006), and previous findings of research (Kuburić, 2002; Maslow, 2001; Roccass et al., 2002). The inner values are more related to the things that we have achieved and perceived as successful, while the external values are focused on honours and awards, so internal values are expected to be more significant predictors of the internal locus of control while social values better predict the non-internal locus or a tendency towards the external locus of control (Bender, 1995; Bojović et al., 2015; Hewes \& Hillman, 2001; Neill, 2005).

Another aim of the research was to determine the degree of difference in the lifestyles and the internal locus of personality control of students of humanistic, religious, technical and sports orientation, which was confirmed by the results, while the gender differences did not appear in the examined domains, so we can conclude that girls and boys do not differ in terms of evaluated life orientations and the internal locus of control.

The results obtained in the domain of lifestyle indicated the presence of significant differences between the students of the Faculty of Theology on the one hand, and the students from other faculties (the Faculty of Technical Sciences, the Faculty of Philosophy and the Faculty of Sport and Physical Education), on the other hand. The first distinguished principal component consisted of influence and religiosity, is mostly the characteristic of the students of the Faculty of Theology, and in a lower degree expressed among the students of the Faculty of Sport and Physical Education, and the least among the others in these groups (the Faculty of Technical Sciences, the Faculty of Philosophy).

Thus, the lifestyle incorporating some aspects of life satisfaction related to domination and the inclination of pragmatism are the most prominent characteristics of the students of the Faculty of Theology (Popadić, 1986). As this lifestyle combines some aspects of life satisfaction by dominance and the tendency of pragmatism (Popadić, 1986), it can be concluded that these students find their source of satisfaction in proper and developed spirituality, in the need to respect the hierarchy of status, but also in some practical elements of everyday life. On the whole, there is a tendency among the students of other 
faculties, characterized by the need to dominate, which is expressed in a lower degree in some aspects of life satisfaction and pragmatism, which includes the dimensions of positive emotions (Neill, 2005; Popadić, 1986).

The reasons for these manifestations of the tendency in the area of lifestyle are multiple. On the one hand, the professional choice of students of religious profiles can point to their orientation towards spirituality that involves a high level of self-renunciation and therefore, this result may represent a response to the awareness of satisfaction. Another possible explanation is that the hierarchy of position and status, important in this profession, stimulates this choice of lifestyles. It can be assumed that this profession is chosen by the individuals who had a lot of experience with religious education during the period of growing up,. Some factors that made them opt for this profession indicate that there are priests' children among them; love for this profession, therefore, formed and developed very early. Likewise, the choice of this profession may have been affected by the factor of secondary education (completed studies of theology).

In the end, their orientation towards specific lifestyles and values could have been affected by their growing up in the environment where a positive attitude toward religion is respected and supported (Dragun, 2011). Motivational aspects of religion, supported during the classes of religious education, church-going and enjoying the rituals and ceremonies that encourage spirituality, certainly predisposed the young theologians for the expression of some elements of positive emotions (Babić et al., 1997; Seligman, 1975). In addition, preference for social interactions in which harmony is prominent and stimulated by religious needs, probably served as the impulse for the expression of specific characteristics that are an integral part of functioning of religiously oriented students (Renner, 2003; Shwartz, 2006).

Although this result seems somewhat unexpected, when interpreting these findings it is reasonable to ask the question whether value preferences are clearly profiled at this stage of development. The problem with this interpretation may lie in the fact that the development stage of young people was not long enough to influence the stabilization characteristics such as lifestyle (Renner, 2003). This means that at this age-level it seems that the young are still not prepared for the differentiation of value constructs of personality such as lifestyles.

In the research segment of the locus of control, the results showed the absence of internal orientation (the students of the Faculty of Theology), and emphasized an external direction which is named a passive strategy of dealing with the problems. Therefore, the accentuated absence of an internal locus of control is most obvious among the students of the Faculty of Theology. These findings are expected, given that these students' learning is dominate by external factors that determine the individual's life and achievement (Dragun, 2012; Seligman, 1975).

On the contrary, with some minor differences between the subgroups, in the group of the students of the Faculty of Technical Sciences, the Faculty of Sport and Physical Education and the Faculty of Philosophy, the findings confirmed internal orientation, or a strong need for the pronounced appreciation of their own "power" and determination (effort, commitment, abilities, activities in the approach to problem solving). Based on this, it can be concluded that the students with the internal locus of control attend mainly these faculties. However, the fact should also be added that the method of studying at these 
faculties, as well as the general atmosphere in relation to the requirements, can potentiate the internal locus of control.

Therefore, the results in the area of the locus of control are quite expected, given that the students of the Faculty of Theology are externally oriented. The accentuated presence of the external locus of control among these students is in accordance with their theoretical orientation, where the external factors governing the individual's life and decisions and choices are dominant (Roccass et al., 2002; Shwartz, 2006).

The dominant internal orientation of other groups of students (the Faculty of Technical Sciences, the Faculty of Philosophy and the Faculty of Sport and Physical Education), probably derives from educational influences where the main characteristics are focus on achievement and active solving and dealing with problems (Roccass et al., 2002). Namely, the need for active engagement and achievement, which is primarily the result of an individual's own abilities and efforts, probably directs these students towards activation by using their own resources at the same time. An individual's orientation to success and experience of success are predominantly determined by the source of personal resources and their active guidance to achievement. Self-efficacy and self-transcendence of the existing difficulties first of all determine the final outcome and direction of events. Taking proper steps, as well as analyzing and revising solutions to a problem, represent integral parts of the internal locus of control (Bender, 1995; Seligman, 1975). Internally oriented individuals actively plan and systematically take measures for a positive outcome in order to overcome life's obstacles and difficulties (Marić \& Novović, 2010).

\section{Conclusion}

The socio-psychological implications of the confirmed relation between the value orientations and the locus of control in students, as well as the relations between professional orientations, individual value system and individual locus of control, have all been identified in this study. However, this also opens the way for new research findings, regarding rapid social transformations directed towards generating new value systems of youth personality and the development of personal characteristics typical of new social contexts and relations. 


\author{
Марија Д. Сакач \\ Миа Р. Марић \\ Универзитет у Новом Саду \\ Педагошки факултет у Сомбору \\ Сомбор (Србија)
}

\title{
ВРЕДНОСНИ СИСТЕМ И ЛОКУС КОНТРОЛЕ КОД СТУДЕНАТА \\ (Превоg In Extenso)
}

Сажетак: Рад се бави анализом вредносних оријентација и локуса контроле код студената хуманистичке, религијске, техничке и спортске оријентације. На узорку од 1146 студената, примењени су упитник за мерење локуса контроле и скала за мерење преферираних стилова живота. Потврђена је повезаност између вредносних оријентација и локуса контроле, као и да се према варијабли животног стила, студенти Богословског факултета статистички значајно разликују од студената осталих факултета. Овој разлици највише доприноси прва главна компонента из простора животних стилова, именована као позитивна емоционалност. Резултати сугеришу да се студенти Богословског факултета статистички значајно разликују од студената осталих факултета и то према основној димензији локуса контроле, именованој као пасивна стратегија суочавања са проблемом.

Кључне речи: личност, локус контроле, вредности, млади.

\section{Увод}

Суштинску компоненту личности сваког појединца чини његов вредносни систем. Људске вредности се дефинишу као когнитивни конструкти који објашњавају индивидуалне разлике у погледу циљева у животу и понашању, и принципа приоритета (Renner, 2003). Десет базичних вредносних оријентација садрже све кључне вредности које се препознају у различитим културама у свету (Shwartz, 2006). Сваку од базичних вредности карактерише опис главног мотивационог циља: самоусмерење (независност у деловању, избор, креирање, истраживање); стимулација (узбуђење, новина, изазови); хедонизам (задовољство и уживање); постигнуће (лични успех кроз демонстрацију компетенција над људима и изворима); моћ (социјални статус, престиж, контрола доминације над људима и изворима); безбедност (сигурност, усклађеност и стабилност друштва, у односима и у личности); прилагођеност (уздржавање од деловања, намера и импулса који могу узнемирити и нарушити социјална очекивања или норме); традиција (поштовање, оданост 
и прихватање обичаја и идеја традиционалне културе или религије); доброчинство (старање о добробити оних за које смо везани); универзалност (разумевање, толеранција, заштита људи и добара). Стога се може закључити да вредности утичу на већину, ако не и на све облике мотивационог понашања (Babić, Irović i Krstović, 1997; Dragun, 2012; Havelka, 1995; Sekulić, 2011). При том, спољашње вредности су усмерене на признања и награде, док се унутрашње вредности више односе на оно што смо постигли, а сами сматрамо успешним (Kuburić, 2002; Maslow, 2001; Roccass, Sagiv, Schwartz, \& Knafo, 2002).

Појму вредности, по свом суштинском садржају, сродни су животни стилови. Сваки избор је израз обликовања властитог живота, где се неки од њих, према Попадићу (1995), бирају аутоматски, а други су резултатат мисаоног процеса. Овај аутор такође наглашава да основно питање које произлази из анализе појединих начина живота, није у томе да ли неко нешто воли, или жели, већ да ли је спреман да начин живота устроји тако да друге активности подреди постизању приоритетних циљева (Popadić, 1995). У својој животној оријентацији и својим животним стиловима, неки појединци су више усмерени на религију, неки други ка спорту или техници, док је вредносни систем хуманистички оријентисаних усмерен на човека, његову егзистенцију и његов психосоцијални развој.

Локус контроле представља базичну димензију личности која најкраће може да се именује као мера у којој људи верују да имају контролу над догађајима. Другим речима, у одређењу локуса контроле кључни појам је перцепција места или локализација мање, односно веће контроле над исходима свог понашања. Локус контроле се први пут појављује као централни конструкт Ротерове теорије социјалног учења (Social learning theory, 1954). Исто тако, он заузима значајно место и у Селиџменовој теорији вероватности (Seligman, 1975), као и у Вајнеровој атрибуционој теорији мотивације и емоција (Weiner, 1986).

Локус контроле са аспекта Ротерове теорије, представља релативно стабилне предиспозиције личности, ка унутрашњем, односно спољашњем локусу контроле. Самоефикасност, као суштинска компонента локуса контроле појединца, значајна је одредница у постављању и реализацији његових циљева. Аутори истичу да од веровања појединца у своју ефикасност зависе његови покушаји успостављања контроле над догађајима и самим тим, очекивања позитивног исхода (Taylor \& McDonald, 1999).

Попадић (1986) у свом приступу локусу контроле, у зависности од циљева, разликује три форме: локус узрочности, опажену контролу и преузимање одговорности. Ако се локус контроле тумачи као једна димензија, представљаће веровање у којој мери исход догађаја зависи од спољашњих или унутрашњих фактора. Локус контроле, посматран као опажена контрола интерналног усмерења, може да се прикаже као могућност остварења постављених циљева. Међутим, појединци са унутрашњим локусом контроле могу запасти у замку немоћи, када су фактори који дефинишу успех спољашњи и када им нису наклоњени. Насупрот томе, екстернално оријентисани појединци могу осетити моћ у ситуацији када прибегавају ритуалима којима покушавају да умилостиве, нпр. моћне друге. То потврђује да и фактори успеха могу да буду спољашњи и унутрашњи. Преузимање одговорности као трећа форма локуса контроле, представља спремност прихватања одговорно- 
сти, с обзиром на то да једна иста ситуација успеха или неуспеха може различито да се тумачи (Popadić, 1986).

Имајући у виду карактеристике и индивидуално опажање догађаја, могу се детаљније описати два основна облика локуса контроле. Интернални локус контроле је одлика оних појединаца који верују да њихова сопствена искуства детерминишу њихове властите вештине и уложени напор. Велика вероватноћа догађаја унутрашње оријентисаних појединаца је под њиховом контролом. Одлике интерналиста се огледају у томе да антиципирају могућност контроле, стога бирају ситуације које им дозвољавају да провере ову контролу.

С друге стране, особе које у већој мери имају спољашњи локус контроле, или особе екстерналног усмерења, индивидуална очекивања стављају под контролу спољашњих фактора (среће, ауторитета, случајности, тежине задатка, и сл.), због чега су склони недостатку упорности и ниском нивоу очекивања. Екстерналисти бирају оне ситуације које их ослобађају одговорности. Међутим, строга подела на екстерналисте и интерналисте није оправдана, с обзиром на постојање великог броја појединаца који припадају мешовитим типовима. Исто тако, интересантно је тврђење Нила (2005) о важности упозорења људи да наивно не прихватају идеју да је унутрашњи локус контроле добар, а да је спољашњи лош.

Локус контроле може да се доведе у везу са бројним процесима и функцијама појединаца. Ова варијабла личности значајно учествује у дефинисању школског постигнућа, што потврђује и анализа интерналне/екстерналне оријентације. Разумевање ефеката контроле и предузимање неких корака ка адекватном усмерењу, може да доведе до много ефикаснијег школовања. Strickland, (1988, према Hewes \& Hillman, 2001) истиче да деца са већим интерналним резултатом показују боље адаптивно понашање и бољи академски успех. Исто тако, Bender (1995) сматра да континуирани неуспех, упркос континуираним покушајима решавања школских задатака, води усвајању спољашњег локуса контроле, што опет, води недостатку мотивације за учење.

Студија спроведена на подацима из истраживања Вредносни систем младих и друштвене промене у Хрватској, Института за друштвена истраживања у Загребу, која је реализована на репрезентативном узорку од 1700 младих оба пола, узраста од 15 до 29 година, с подручја целе Хрватске (Ilišin \& Radin, 2002), имала је за циљ анализу утицаја социо-демографских варијабли - пол, узраст, степен образовања, место становања и брачни статус на поимање вредности испитаника (Bouillet, 2004). Резултати су показали да свих пет испитиваних социо-демографских обележја младих има утицај на њихове породичне вредности. Место становања и школска спрема испитаника показале су се чиниоцима који, у највећој мери, имају везе с вредностима младих, затим следе пол и брачни статус, док је у најмањој мери са вредностима повезан узраст испитаника.

Истраживање феномена вредности и вредносних оријентација младих које је реализовано на узорку од 252 студента, будућих учитеља и васпитача, уз примену Рокачеве листе вредности, показало је да постоји висок степен уједначености резултата студената, када је реч о терминалним вредностима које представљају пожељна стања и циљеве, док постоје извесне разлике у погледу инструменталних вредности, односно, идеализованих начина понашања са сврхом остваривања 
терминалних вредности. Такође, утврђено је да су студенти учитељских факултета оријентисани на породичну сигурност, срећу, искрено пријатељство, унутрашњи склад, што су све њихове доминантне терминалне вредности, а од инструменталних вредности издвајају се поштење, одговорност и способност (Bojović, Vasiljević, \& Sudzilovski, 2015).

Истраживање спроведено 2009. године међу 254 ученика завршних разреда средњих школа у Задру, показало је резултате сличне онима добијеним у другим регионима Хрватске, који говоре о томе да су од испитиваних вредности младима најважнији аспекти вредности које се односе на добре односе са другима, па се тако посебно издвајају пријатељство, добри односи у породици, поштење и љубав, поред здравља, које се показало такође као доминантна вредност код младих. Резултати указују да вредности конвенционалне моралне оријентације чине главни повезујући чинилац с тежњом ка самоостварењу (Dragun, 2012).

У истраживању Попадића (1995), на узорку адолесцената утврђени су следећи доминантни животни стилови: породично-сентиментални, алтруистички, спознајни и утилитарни, док су се религијско-традиционални и оријентација на моћ показали као најмање популарни стилови живота. Младеновић и Кнебл (2000), истражујући животне стилове младих, долазе до три значајна фактора. У првом скупу животних стилова издваја се фактор који репрезентује животни стил усмерен на самог појединца. Оријентисаност на примарну групу и ширу заједницу дефинише други идентификациони фактор, а у трећем скупу животних стилова, који је усмерен на опште људске вредности, доминира спознајни, прометејски и алтруистички животни стил. Истраживање о животним стиловима, интересима и вредностима у оквиру Шелове студије у Немачкој (Shell, 2002, према Becker, 2004), на узорку од 2500 испитаника узраста од 12-25 година, показало је да породица и школа представљају важне факторе животних стилова и вредности младих.

Студија спроведена на студентској популацији која је имала за циљ испитивање ставова студената о присутности, карактеристикама и узроцима кризе моралних вредности у друштву, са посебним освртом на перципирање односа моралних вредности са факторима деловања породице, школе и других друштвених институција, показала је да се у том смислу посебно издваја улога породице, школе и медија, као и њихово међусобно деловање у правцу формирања моралних вредности деце и младих. Оно што забрињава јесте податак да код студената доминирају страх, несигурност, песимизам и неповерење у личне способности у погледу могућности за деловање на кризу моралних вредности. Поред тога, уочена је и извесна недоследност код студената када је реч о моралном деловању (Budimir-Ninković \& Stevanović, 2013).

Налази истраживања које су спровели Сакач и Младеновић (2005), на репрезентативном узорку ученика гимназија и средњих школа у Новом Саду, о интерналном локусу контроле, као значајној детерминанти у мултивредносним облицима постигнућа и компетентности, указали су на различите облике интерналног локуса контроле. Један од њих се односи на контролисање школског успеха, односно индивидуалну компетентност у области одлучивања и рада, а други на емоционалну компетентност (Sakač \& Mladenović, 2005). Mamlin, Harris and Case (2001, према 
Neill, 2005) утврдили су правилност по којој су мушкарци склонији унутрашњем локусу контроле у односу на жене.

У испитивању које су спровели Ule \& Kuhar (2002) на узорку словеначке омладине, здравље се налази на врху лествице, затим следи искрено пријатељство, породични живот и слобода мисли и деловања. Прве три одражавају традиционализам и ствари личне природе, док четврта вредност представља пример експресивне вредности, која се повезује са идеалистичком концепцијом света и живота. Међу вредностима које су испитаници најниже вредновали налази се дистинктивна група статуса материјалистичке или хедонистичке вредности (добро материјално стање, узбудљив живот, ауторитарност, лидерство и моћ над другима). Упоређивањем резултата испитивања Млади 2010. са Млади 2000, може се закључити да су интереси ниже оцењени, једино што је порастао интерес за уживање у храни и пићу (Naterer \& Quiet, 2011).

Aluja \& Garcia (2004) су идентификовали три фактора - друштвена моћ, ред и доброчинство, у скупу од 25 вредности. Већину младих у Русији карактеришу вредности које се тичу материјалног статуса (Zorkaia \& Duik, 2005). Том приликом, само половина испитаника сматрала је да је високо образовање услов успеха у животу, док најмлађи испитаници (између 16 и 19 година) највише вреднују високо образовање.

На основу приказаних теоријских концепција (Roccas et al., 2002; Shwartz, 2006; Seligman, 1975; Taylor \& McDonald, 1999) и резултата претходних студија, који говоре о постојању разлика у вредностима и локусу контроле између младих различитих образовних и професионалних усмерења и различитог пола (Bojović et al., 2015; Bouillet, 2004; Ilišin \& Radin, 2002; Marić \& Novović, 2010; Marin, Infante, \& Troyano, 2001; Mamlin et al., 2001, према Neill, 2005; Рopadić, 1995), изведена је основна претпоставка овог истраживања да постоји повезаност између вредносних оријентација и локуса контроле, као и да се студенти различитих факултета и различитог пола разликују у преферираним животним вредностима и степену поседовања интерналног локуса контроле.

\section{Метод}

Проблем овог истраживања јесте питање да ли постоји повезаност између вредносних оријентација и локуса контроле, као и да ли су и у ком степену карактеристике студената везане за пол и њихово професионално усмерење, повезане са њиховим вредносним системом и унутрашњим локусом контроле.

У складу са тим, циљ истраживања је испитати постојање релације између вредносних оријентација и локуса контроле код студената, као и разлика у вредносном систему и локусу контроле студента, с обзиром на њихов пол и врсту студија.

Истраживање је спроведено током академске 2014/15. године, на узорку од 1146 студената оба пола, 636 мушког (55,49\%) и 510 женског (44,51\%), просечне старости 21,79 година, година студија: од 1. до 4. (5.). Структура узорка је приказана у Табели 1. Узорак је случајан. Укључена су четири факултета и тежња је била да се обухвате факултети различитих образовних оријентација. Укупан број учесника одређен је пропорционално укупном броју студената сваког факултета укључених у узорак. 
Када је реч о етичким принципима, истраживање је било анонимног карактера. Испитаницима је објашњено да ће подаци бити коришћени искључиво у истраживачке сврхе. Претоходно је обезбеђена сагласност етичког одбора установе у којој је истраживање реализовано.

Као инструменти у овом истраживању су коришћени:

- Скала за мерење преферираних стилова живота, V-PAL (Вредности Пожељни атрибути личности, Havelka, 1998) - укључује серију од дванаест описа вредновања животних оријентација. Сваки опис формулисан је у виду тврдње чији се степен слагања процењује петостепеном скалом процене, заокруживањем једног од пет понуђених одговора (од „не слажем се” до „у потпуности се слажем”), па тако виши степен слагања означава више прихваћену дату вредност. Шест оријентација означава усмереност на индивидуалне циљеве: сигурност (егзистенцијална сигурност - пример ставке: имати сталан и сигуран посао, који осигурава пристојан и сигуран живот, марљивим радом обезбедити задовољење својих потреба), зарада (материјална корист - имати велику зараду, бити богат), пријатност (хедонизам - живети весело и безбрижно, водити живот испуњен угодностима и задовољствима, без великих напора), самосталност (независност од других - самостално одлучивати, бити самосталан у раду, независтан од других), усавршавање (самоактуализација - да стално развија своје способности, таленте и амбиције и усавршава се као личност), религиозност (посвећеност својој вери - поштовати правила и захтеве вере, ускладити живот и обичаје са религијом). Шест оријентација означава усмереност на социјалне циљеве: доминација или утицајност (социјална моћ - управљати, руководити, доносити важне одлуке, бити утицајна личност), популарност (статус у јавном животу - бити познат и популаран, појављивати се у медијима), сазнавање (истраживање - откривати нова сазнања, бавити се науком и истраживањем), сарадња (кооперативни дух - поштовати друге, градити сарадњу, толеранцију и заједништво), помагање (алтруизам - помагање људима у невољи, чинити добро и по цену великих одрицања и напора), праведност (прометејство стварање бољег, праведнијег друштва, искорењивање сиромаштва и зла, уз велике напоре). Укупан скор се означава као збирни резултат вредности постигнутих на ајтемима који означавају шест фактора индивидуалних и социјалних циљева. Скала има задовољавајуће метријске показатеље - Хронбахова а износи 0.78 , тест - ретест поузданост је 0.72, при чему је у овом истраживању Хронбах а такође висока и износила је 0.75 .

- Скала за мерење интерналног локуса контроле, LOK IM-2, садржи 16 четворостепенованих тврдњи Ликертовог типа, са избором алтернативних одговора: потпуно тачно, делимично тачно, делимично нетачно, потпуно нетачно). Висок резултат на скали означава интерналну оријентацију. Супротно, ниски скорови указују на то да испитаник нема интернални локус контроле, али не мора истовремено значити и то да има екстернални локус контроле, иако се таква могућност не искључује. Скала LOK IM-2 представља скраћену и ревидирану форму скале LOK IM-1 (Sakač, 2003). Примери ставки су: Мој успех у школовању највише зависи од мојих способности и уложеног труда, Покушавам да решим потешкоће, јер се оне неће решити саме од себе, Сматрам да моја будућност највише зависи од мене, Однос других према мени највише зависи од мене и мог понашања, Од мене највише 
зависи колико ћу успети у животу и сл. Метријске карактеристике скале су следеће: Хронбах $\alpha=0.75$, а стандардизовани коефицијент $\alpha$ износи 0.76. Релативно добре метријске карактеристике ове скале оправдавају њену примену, што се показало и у овом истраживању $(\alpha=0.71)$. Ајтем-тотал корелације се крећу од 0.64 до 0.85 , са просечном интер-ајтем корелацијом од 0.76 (у овом истраживању 0.73 , што указује да скала има задовољавајућу интерну кохерентност). Факторска структура је такође показала да скала има јединствен предмет мерења, при чему се факторска засићења крећу у распону 0.79 до 0.94 .

\section{Резултати}

У оквиру статистичке обраде података, коришћена је вишеструка регресиона анализа за испитивање односа између локуса контроле и вредносних оријентација студената. У регресији, критеријумска варијабла је била локус контроле, док су предиктори били шест индивидуалних и друштвених вредносних оријентација. Двофакторска ANOVA је коришћена за испитивање полних и факултетских разлика у локусу контроле и вредносним оријентацијама међу студентима. Претходно је изведена факторска анализа, с циљем одређивања латентне структуре варијабли.

у Табели 2 и Табели 3 приказани су резултати анализе варијансе (ANOVE), којом су се испитивале разлике међу студентима у погледу преферираних животних стилова. Пошто је величина узорка у категоријама била различита, при одређивању претпоставке хомогености варијансе, примењен је Левенов тест. Вредност Левеновог теста је показала да је ова претпоставка испоштована, што је показатељ да је тест примењен под претпоставком хомогене варијансе (Lev.stat.=1.18; p=0.734 за утицајност; Lev.stat. $=1.12$; р=0.693 за религиозност). Ови резултати потврђују да се код компонената животних стилова - утицајности и религиозности, уочавају статистички значајне разлике између испитаника различите факултетске припадности, док се пол и интеракција факултета и пола нису показале значајним. Шефеов тест је потврдио да се студенти Богословског факултета значајно разликују од студената осталих факултета (p<.000). Најмање уочене разлике у компонентама животних стилова остварене су између студената Техничких наука и студената Факултета спорта и физичког васпитања.

Како је у домену животних стилова претходно факторском анализом екстрахована прва главна компонента коју одликује висок скор на димензијама утицајности и религиозности (просечна корелација ставки са фактором 0.64), то сугерише да овај животни стил највише преферирају студенти Богословског факултета, а мање студенти Факултета спорта и физичког васпитања (ФСФВ) и Факултета техничких наука (ФТН), а затим и студенти Филозофског факултета (ФФ).

Тестови значајности разлика у домену интерналног локуса контроле (Табела 4) потврђују статистички значајне разлике између студената различитих факултета, при чему се пол и интеракција факултета и пола ни овде нису показале значајним. С обзиром да је величина узорка у категоријама била различита, примењен је Левенов тест за испитивање претпоставке хомогености варијансе. Вредност Левеновог теста је показала да је ова претпоставка испоштована, што је показатељ да је тест примењен под претпоставком хомогене варијансе (Lev. 
stat.=1.26; p=0.827). Највеће разлике, према налазима Шефеовог теста, утврђене су између студената Богословског, с једне, и студената осталих факултета, с друге стране. Исто тако, овај тест омогућава извођење закључка да нису потврђене разлике између студената осталих факултета (ФТН-а, ФФ-а и ФСФВ-а). С обзиром да је претходно факторском анализом у оквиру домена интерналног локуса контроле изолована прва главна компонента, која је именована као пасивна стратегија суочавања с проблемом (просечна корелација ајтема са фактором је 0.68), што одражава снижену интерналну оријентацију, ово код студената осталих факултета указује на њихово веће или мање интернално усмерење, односно интернални локус контроле.

У табелама 5 и 6 приказани су резултати анализе вишеструке регресије која је тестирала везу између локуса контроле и вредносних оријентација студената. Критеријуми су били унутрашњи локус контроле, а предиктори шест вредносних оријентација - индивидуалних и друштвених.

Табела 6 показује да су значајни предиктори унутрашњег локуса контроле код студената вредносне оријентације - независност од других, усавршавање и учење. Вредносне оријентације - религиозност, кооперативни дух - поштовање других и помоћ, негативно су повезане са унутрашњим локусом контроле.

\section{Дискусија}

Главни циљ истраживања био је испитати однос између система вредности и локуса контроле код студената. Резултати су показали да су различити циљеви унутар група индивидуалних и друштвених вредносних оријентација значајни предиктори унутрашњег локуса контроле код студената. У оквиру појединачних вредносних циљева, независност од других, усавршавање и религиозност, показали су се као значајни предиктори локуса контроле. Учење, кооперативни дух - поштовање других и помагање су друштвене вредносне оријентације које значајно предвиђају локус контроле код студената.

Може се закључити да млади људи са јаком тенденцијом да буду независни од других и тежњом за самоактуализацијом, константним учењем и развијањем својих способности, талената, амбиција и личности, имају предиспозицију за унутрашњи локус контроле. Такође, они млади људи који су склони религиозности, са духом сарадње и склоношћу да поштују и помажу другима, мање су склони да имају унутрашњи локус контроле, али то још увек не значи да ће сигурно манифестовати карактеристике екстерног локуса контроле.

Ови резултати су очекивани у односу на доминантне теорије локуса контроле (Taylor \& McDonald, 1999; Weiner, 1986) и вредносних оријентација (Havelka, 1995; Renner, 2003; Shwartz, 2006), као и претходне налазе истраживања (Kuburić, 2002; Maslow, 2001; Roccass et al., 2002). Унутрашње вредности више се односе на ствари које смо постигли и перципирали као успешне, док су спољашње вредности усмерене на почасти и награде, па се очекује да су унутрашње вредности значајнији предиктори унутрашњег локуса контроле, те да ће друштвене вредности боље предвидети не-унутрашњи локус или тенденцију ка спољашњем локусу контроле (Bender, 1995; Bojović et al., 2015; Hewes \& Hillman, 2001; Neill, 2005). 
Циљ спроведеног истраживања био је такође и да се испитају и утврде нивои разлика у изражености животних стилова и интерналног локуса контроле личности код студената хуманистичке, религијске, техничке и спортске оријентације, што је и потврђено резултатима, док се разлике у испитиваним доменима с обзиром на пол студената нису показале, па можемо закључити да се девојке и младићи не разликују у погледу вреднованих животних оријентација и интерналног локуса контроле.

Добијени резултати у простору животног стила указали су на присуство статистички значајних разлика између студената Богословског факултета, на једној страни, и студената осталих факултета (ФТН-а, ФФ-а и ФСФВ-а), на другој страни. Издвојена прва главна компонента коју чине утицајност и религиозност, у већој мери је одлика студената Богословског факултета, а у мањој мери је изражена код студената Факултета спорта и физичког васпитања, а затим и код осталих из ове групе (ФТН-а, ФФ-а).

Дакле, животни стил који обједињује неке аспекте задовољства животом везаним за доминацију и склоност прагматичности, најизразитија је одлика студената Богословског факултета (Рораdić, 1986). Такође, може се закључити да ови студенти налазе извор задовољства у одабраној и изграђеној духовности, потреби за поштовањем хијерархије статуса, али и неким практичним елементима свакодневног живота. У целини гледано, постоји тенденција да је код студената осталих факултета мање изражена потреба за доминацијом као извором задовољства животом и прагматичношћу (Neill, 2005; Popadić, 1986).

Разлози за овакве облике манифестовања тенденција у простору животног стила су вишеструки. С једне стране, професионални избор студената религијског профила може да укаже на њихову оријентацију ка духовности која подразумева велики степен одрицања и сходно томе, овакав резултат може да представља реакцију на свест о задовољству. Друго, могуће објашњење је да хијерархија положаја и статуса, значајна у овој професији, потенцира овакав избор стилова живота. Може се претпоставити да су се за ово професионално усмерење определили појединци који су током свог одрастања имали много додирних тачака са религијским образовањем. Неки чиниоци који су их определили за овај позив указују на то да међу њима има деце свештеника, код којих је љубав према овом позиву формирана и развијена веома рано. Исто тако, на избор овог занимања могао је да утиче и фактор средњошколског образовања (завршена Богословија).

На крају, на њихово усмерење ка одређеним животним стиловима и вредностима могло је да утиче и њихово одрастање у окружењу у коме је поштован и негован позитиван однос према религији (Dragun, 2011). Мотивациони аспекти религије, подстицани кроз часове веронауке, одласке у цркву и уживање у ритуалима и обредима које пружа духовност, свакако да су определили младе богослове за израженост неких елемената позитивне емоционалности (Babić et al., 1997; Seligman, 1975). Осим тога, склоност социјалним интеракцијама у којима долази до изражаја хармонија стимулисана религијским потребама, вероватно је послужила као подстицај за манифестовање специфичних карактеристика, које су саставни део функционисања студената религијског усмерења (Renner, 2003; Shwartz, 2006). 
Иако овај резултат делује помало неочекивано, приликом тумачења налаза, оправдано је поставити и питање да ли су у овом животном добу јасно профилисане вредносне преференције. Проблем са оваквом интерпретацијом може да буде и у томе што развојни стадијум у коме се налазе млади није био довољно дуг да би утицао на стабилизацију карактеристика као што је животни стил (Renner, 2003). То значи да на овом узрасном нивоу, изгледа још увек не постоји спремност за диференцијацију вредносних конструката личности као што су животни стилови.

У истраживачком сегменту локуса контроле, добијени налази су указали на одсуство интерналне оријентације (студенти Богословског факултета), односно наглашено усмерење које је именовано као пасивна стратегија суочавања са проблемом. Дакле, наглашено одсуство интерналног локуса контроле најуочљивије је код студената Богословског факултета. Овакви налази су очекивани, с обзиром на то да у учењу ових студената доминирају екстернални фактори који одређују живот појединца и његово постигнуће (Dragun, 2012; Seligman, 1975).

Супротно томе, уз извесне мање разлике између појединих подгрупа, у групи студената Факултета техничких наука, Факултета спорта и физичког васпитања и Филозофског факултета, налази су потврдили интерналну оријентацију, односно изражену потребу за наглашеним уважавањем сопствених „моћи” и детерминација (труда, залагања, способности, активности у приступу решавању проблема). Из тога се може извести закључак да се на ове факултете углавном уписују студенти са интерналним локусом контроле. Међутим, треба додати и чињеницу да и начин студирања на овим факултетима, као и општа клима у вези са захтевима, могу да потенцирају интернални локус контроле.

Налази из области локуса контроле су дакле сасвим очекивани, с обзиром на то да су студенти Богословског факултета мање интернално оријентисани. Наглашено присуство екстерналног локуса контроле код ових студената је у складу са њиховом теоријском оријентацијом у којој доминирају екстернални фактори који управљају животом појединца и његовим одлукама и изборима (Roccass et al., 2002; Shwartz, 2006).

Доминантна интернална оријентација друге групе студената (ФТН-а, ФФ-а и ФСФВ-а), вероватно произлази из васпитног утицаја чије су главне одлике усмереност на постигнуће и активно решавање и суочавање са проблемима (Roccass et al., 2002). Наиме, потреба за активним ангажовањем и постигнућем, која је првенствено резултат сопствених снага и залагања, вероватно опредељује ове студенте у смеру активирања и, при томе, кориштења сопствених потенцијала. Оријентација појединца на успех и доживљај успеха, доминантно су детерминисани извором личних ресурса и њиховим активним усмеравањем ка постигнућу. Самоефикасност и самопревазилажење постојећих тешкоћа у првом реду одређују коначан исход и смер догађаја. Предузимање адекватних корака, као и њихова анализа и ревизија у решавању проблема, саставни су део интерналног локуса контроле (Bender, 1995; Seligman, 1975). Интернално оријентисани појединци активно планирају и систематски предузимају мере за позитиван исход превазилажења животних препрека и потешкоћа (Marić \& Novović, 2010). 


\section{Закључци}

Социо-психолошке импликације потврђене повезаности вредносних оријентација и локуса контроле код студената, као и релације професионалних оријентација, индивидуалног вредносног система и локуса контроле, идентификоване су у овом истраживању. Међутим, на овај начин се отвара пут и за нове истраживачке налазе, с обзиром да убрзане друштвене трансформације иду у правцу генерисања нових вредносних система личности младих и развоја личних одлика карактеристичних за нове друштвене контексте и релације.

\section{REFERENCES / ЛИTEPATУPA}

Adler, A. (1989). Knowledge of life. Novi Sad: Matica Srpska [In Serbian]

Aluja, A., Garcia, L. F. (2004). Relationships between big five personality factors and values. Social Behavior and Personality, 32(7), 619-626. doi: 10.2224/sbp.2004.32.7.619

Babić, N., Irović, S., Krstović, J. (1997). Adult-value system, educational practice and developmental effects. Društvena istraživanja, 4-5(30-31), 551-557

Becker, M. (2004). The life style and value-orientation of German youth today. Heidelberg: University of Education Heidelberg /online/. Retrieved on $11^{\text {th }}$ March 2016 from http://www.fromm-gesellschaft.eu/images/pdf-Dateien/Becker_M_2004

Bender, W. N. (1995). Learning disabilities: characteristics, identification and teaching strategies (2nd ed.). Needham Heights, Mass: Allyn \& Bacon

Bojović, Ž., Vasiljevic, D., Sudzilovski, D. (2015). Values and value orientations of students, future primary school teachers and preschool teachers. Croatian Journal of Education, 17(4), 11-35. doi: 10.15516/cje.v17i0.1339

Bouillet, D. (2004). The relation of young people to the values and factors of family life. Sociologija sela, 163-164 (1-2), 173-194

Budimir-Ninković, G., Stevanović, N. (2013). University students' attitudes about morality crisis today. Croatian Journal of Education, 15(3), 741-776

Dragun, A. (2011). Religiosity of graduates in Zadar. Sociologija i prostor, 49(1), 93-94

Dragun, A. (2012). Free time and the values of graduates in Zadar. Crkva u svijetu, 47(4), 487-513

Havelka, N. (1995). Value orientations of students and their expectations of future interest. Psihološka istraživanja, 7, 81-125 [In Serbian]

Havelka, N. (1998). Value orientations of adolescents: values and context. Psihologija, 4, 343-364 [In Serbian]

Hewes, D. W., \& Hailman, W. N. (2001). Locus of control as a tool historians. Grand Rapids: Defender of Froebel, Froebel Foundation USA

Ilišin, V., Radin, F. (2002). Young before the third millennium. Zagreb: Institut za društvena istraživanja

Kuburić, Z. (2002). Religion and freedom. Novi Sad: Centar za empirijska istraživanja religije [In Serbian]

Marin, M., Infante, E., Troyano, Y. (2001). Personality and academic productivity in the university student. Social Behavior and Personality: An International Journal, 3(29), 299-306 
Marić, M., Novović, Z. (2010). Factors that contribute to the appearance of dysphonic reactions in adolescence. Pedagoška stvarnost, 56(3-4), 317-325 [In Serbian]

Maslow, A. H. (2001). About living values - Selected essays on psychology of values. Beograd: Žarko Albulj [In Serbian]

Mladenović, U., Knebl, J. (2000). Value orientations and preferences of lifestyles of adolescents. Psihologija, 3-4, 435-454 [In Serbian]

Naterer, A., Miran, L. (2011). Youth 2010 in the context of the study of young people. In L. Miran (Ed.), Youth 2010 - a social profile of young people in Slovenia (pp. 33-41). Maribor: Aristej

Neill, J. (2005). Locus of control a class tutorial /online/. Retrieved on 30 ${ }^{\text {th }}$ November 2015 from http://www.wilderdom.com/games/descriptions/LocusOfControlExercise. html

Popadić, D. (1986). Locus control and attribution as an approach to the interpretation of the cause of achievement. (Magister's thesis). Filozofski fakultet Univerziteta u Beogradu, Beograd [In Serbian]

Popadić, D. (1995). Adult and generational differences in the preference of lifestyles. Psihološka istraživanja, 7, 71-88 [In Serbian]

Renner, W. (2003). Human values: a lexical perspective. Personality and Individual Differences, 34, 127-141. doi: 10.1016/S0191-8869(02)00037-5

Roccas S., Sagiv, L., Schwartz, S. H., Knafo, A. (2002). The Big Five personality factors and personal values. Personality and Social Psychology Bulletin, 28(6), 789-801.doi: $10.1177 / 0146167202289008$

Sakač, M. (2003). Self-concept, locus of control and some conjectural dimensions of successful and less successful students. (Magister's thesis). Filozofski fakultet Univerziteta $\mathrm{u}$ Novom Sadu, Novi Sad [In Serbian]

Sakač, M., \& Mladenović, U. (2005). School achievement of pupils and structure of internal control locus. In M. Franceško i M. Zotović (Eds.), Personality in a Multicultural Society 5 - Psychosocial Aspects of Social Transition in Serbia (pp. 106-114). Novi Sad: Filozofski fakultet [In Serbian]

Seligman, M. (1975). Helplessness: on depression, development and death. San Francisco, CA: W. H. Freeman

Schwartz, H. S. (2006). Basic human values: Theory, measurement, and applications. Revue francaise de sociologie, 47(4), 244-288

Sekulić, D. (2011). Value-ideological orientations as a consequence of social changes. Politička misao, 48(3), 58-63 [In Croatian]

Taylor, I. A., McDonald, A. D. (1999). Religion and the five factor model of personality: An exploratory investigation using a Canadian university sample. Personality and Individual Differences, 27, 1243-1259

Ule, M., Kuhar, M. (2002). Contemporary Youth: The Challenge of Change. In V. Miheljak (Ed.), Youth 2000 - Slovene youth at the turn of the third millennium (pp. 39-47). Maribor: Aristej

Weiner, B. (1986). An Attributional Theory of Motivation and Emotion. New York: SpringerVerlag

Zorkaia, N., Diuk, N. M. (2005). The values and attitudes of Russia's young people. Russian Education and Society, 47(6), 6-32 


\section{APPENDIX / ПРИЛОЗИ}

Table 1: Distribution of the sample according to the type of faculty

Табела 1: Дистрибуција узорка на основу врсте факултета

\begin{tabular}{|c|c|c|}
\hline $\begin{array}{l}\text { Tyре of faculty } \\
\text { Врста факултета }\end{array}$ & $\begin{array}{l}f \\
\Phi\end{array}$ & $\%$ \\
\hline $\begin{array}{l}\text { Faculties of Theology in Belgrade and Novi Sad/ } \\
\text { Богословски факултети у Београду и Новом Саду }\end{array}$ & 180 & 15.7 \\
\hline $\begin{array}{l}\text { Faculty of Philosophy in Novi Sad/ } \\
\text { Филозофски факултет у Новом Саду }\end{array}$ & 335 & 29.21 \\
\hline $\begin{array}{l}\text { Faculty of Technical Sciences in Novi Sad / } \\
\text { Факултет техничких наука у Новом Саду }\end{array}$ & 291 & 25.84 \\
\hline $\begin{array}{l}\text { Faculty of Sport and Physical Education in Novi Sad / } \\
\text { Факултет спорта и физичког васпитања у Новом Саду }\end{array}$ & 340 & 29.25 \\
\hline Total/ Укупно & 1146 & 100.00 \\
\hline
\end{tabular}

Note: $\mathrm{f}$ - frequency; \% - percentage; Напомена: $Ф$ - фреквенција; \% - проценат

Table 2: Two-factor ANOVA tests of significance in the area of lifestyles - influence Табела 2: Двофакторска ANOVA тестирања разлика у вредносним оријнтацијама домен утицајности

НАЗАД

BACK

\begin{tabular}{|l|c|c|c|c|c|}
\cline { 2 - 6 } \multicolumn{1}{c|}{} & Effect & df & MS & F & p \\
\hline Gender/ Пол & 0.02 & 1 & .029 & .048 & .813 \\
\hline Faculty/ Факултет & 0.07 & 3 & 50.316 & 64.281 & $.000^{* *}$ \\
\hline $\begin{array}{l}\text { Gender*Faculty/ } \\
\text { Пол*Факултет }\end{array}$ & 0.01 & 3 & .853 & 1.467 & .291 \\
\hline
\end{tabular}

Note: effect - effect size; df - degrees of freedom; MS - mean square; F - F-test, ${ }^{* *}$ level of significance $\mathrm{p}<.01$.

Легенда: effect - величина ефекта; df - степени слободе; MS - просечан квадрат; F - Ftest, ${ }^{* *}$ ниво значајности $\mathrm{p}<.01$

Table 3: Two-factor ANOVA tests of significance in the area of lifestyles - religiousness Табела 3: Двофакторска ANOVA тестирања разлика у вредносним оријентацијама - домен религиозности

\begin{tabular}{|c|c|c|c|c|c|c|}
\hline \multirow[t]{2}{*}{ НАЗАД } & Gender/ Пол & 0.03 & 1 & .037 & .054 & .796 \\
\hline & Faculty / Факултет & 0.09 & 3 & 48.629 & 61.315 & $.000^{* *}$ \\
\hline & $\begin{array}{l}\text { Gender*Faculty/ } \\
\text { Пол*Факултет }\end{array}$ & 0.02 & 3 & .914 & 1.578 & .366 \\
\hline
\end{tabular}

Note: effect - effect size; df - degrees of freedom; MS - mean square; F - F-test, ${ }^{* *}$ level of significance $\mathrm{p}<.01$.

Легенда: effect - величина ефекта; df - степени слободе; MS - просечан квадрат; F - Ftest, ${ }^{\star *}$ ниво значајности $\mathrm{p}<.01$. 
Table 4: Two-factor ANOVA tests of significance in the area of the internal locus of control Табела 4: Двофакторска ANOVA тестирања разлика у интерналном локусу контроле

\begin{tabular}{|l|c|c|c|c|c|}
\cline { 2 - 6 } \multicolumn{1}{c|}{} & Effect & df & MS & F & p \\
\hline Gender/ Пол & 0.04 & 1 & 1.214 & 1.478 & .326 \\
\hline Faculty/ Факултет & 0.11 & 3 & 24.173 & 27.893 & $.000^{* *}$ \\
\hline $\begin{array}{l}\text { Gender*Faculty/ } \\
\text { Пол*Факултет }\end{array}$ & 0.08 & 3 & 2.686 & 2.931 & .359 \\
\hline
\end{tabular}

Note: effect - effect size; df - degrees of freedom; MS - mean square; F - F-test, ${ }^{* *}$ level of significance $\mathrm{p}<.01$.

Легенда: effect - величина ефекта; $\mathrm{df}$ - степени слободе; MS - просечан квадрат; F - Ftest, ${ }^{*}$ ниво значајности $\mathrm{p}<.01$.

Table 5: The coefficient of multiple correlation and the assessment of the significance of the regression model

Табела 5: Коефицијент вишеструке корелације и процена значајности

НАЗАД

BACK

НАЗАД

BACK регресионог модела

\begin{tabular}{|c|c|c|c|c|c|}
\hline $\mathrm{R}$ & $\mathrm{R}^{2}$ & Adjusted $\mathrm{R}^{2}$ & Std. error & $\mathrm{F}$ & $\mathrm{p}$ \\
\hline .791 & .626 & .717 & 2.13871 & 18.124 & .000 \\
\hline
\end{tabular}

R- coefficient of multiple correlation; $\mathrm{R}^{2}$ - coefficient of multiple determination, $\mathrm{p}$ - significance level

R- коефицијент мултипле корелације; $\mathrm{R}^{2}$ - коефицијент мултипле детерминације, $\mathrm{p}$ ниво значајности

Table 6: Partial contributions of predictors

Табела 6: Парцијални доприноси предиктора

\begin{tabular}{|c|c|c|c|}
\hline $\begin{array}{l}\text { Individual goals - values orientation } \\
\text { Индивидуални циљеви - вредносне оријентације }\end{array}$ & $\beta$ & $\mathrm{t}$ & $\mathrm{p}$ \\
\hline Security/ Сигурност & .354 & 3.892 & .054 \\
\hline Earnings/ Зарада & .227 & 2.251 & .036 \\
\hline Hedonism/ Хедонизам & .189 & 2.175 & .068 \\
\hline Independence from others/Независност & .731 & 7.236 & .000 \\
\hline Refinement/ Усавршавање & .529 & 5.608 & .001 \\
\hline Religiousness/ Религиозност & -.672 & -6.458 & .001 \\
\hline \multicolumn{4}{|l|}{$\begin{array}{l}\text { Social goals - values orientation } \\
\text { Социјални циљеви - вредносне оријентације }\end{array}$} \\
\hline $\begin{array}{l}\text { Domination or influence/ } \\
\text { Доминација или утицај }\end{array}$ & .217 & 2.983 & .037 \\
\hline Popularity/ Популарност & .296 & 2.541 & .079 \\
\hline Learning/Учење & .489 & 4.315 & .005 \\
\hline $\begin{array}{l}\text { Cooperative spirit-respect for others } \\
\text { Сарадљивост и поштовање других }\end{array}$ & -.582 & -5.262 & .001 \\
\hline Help/ Помагање & -.703 & -7.014 & .000 \\
\hline Justice/ Праведност & .309 & 3.472 & .038 \\
\hline
\end{tabular}

